\title{
UJI EKSTRAK KULIT BATANG NANGKA (Artocarpus heterophylus L.) TERHADAP Salmonella typhi
}

\author{
ANALYSIS OF BARK JACKFRUIT EXTRACT (Artocarpus \\ heterophylus L.) FOR Salmonella typhi
}

\author{
Dwi Nur Rikhma Sari ${ }^{1}$, Ismul Mauludin Al Habib ${ }^{2}$, Eka Rachmawati ${ }^{3}$ \\ Institut Keguruan dan Ilmu Pendidikan (IKIP) Jember \\ Email: dnrs129_dinnurrisa@yahoo.com
}

\begin{abstract}
ABSTRAK
Tujuan penelitian untuk menguji ekstrak kulit batang nangka (Artocarpus heterophylus L.) terhadap Salmonella typhi. Penelitian ini merupakan penelitian eksperimen dengan menggunakan 4 konsentrasi perlakuan 0\%, 25\%, 50\%, 75\% dan konsentrasi $100 \%$ ekstrak kulit batang nangka terhadap bakteri Salmonella typhi. Data parameter penelitian yang diamati adalah zona bening di sekitar kertas cakram yang telah direndam dalam ekstrak kulit batang nangka dengan konsentrasi 25\%, 50\%, 75\% dan 100\%. Zona bening disekitar kertas cakram disebut Daerah Hambat Pertumbuhan (DPH). Data dianalisis secara statistik dengan menggunakan uji Kruskall-Wallis pada taraf $\alpha=0,005$ dengan menggunakan software SPSS 23.0, dan uji lanjutan Duncan's untuk menguji perbedaan antar perlakuan. Hasil uji menunjukkan bahwa variasi konsentrasi ekstrak kulit batang nangka berpengaruh terhadap pertumbuhan bakteri Salmonella typhi, kemudian dari uji Duncan's juga diketahui jika perlakuan 100\% memberikan efek yang paling signifikan atau berbeda nyata.
\end{abstract}

Kata kunci: Artocarpus heterophylus, Salmonella typhi, uji daya hambat pertumbuhan

\begin{abstract}
The research objective was to test jackfruit bark extract (Artocarpus heterophylus L.) against Salmonella typhi. This study was an experimental study using 4 treatment concentrations of 0\%, 25\%, 50\%, 75\% and concentration of $100 \%$ jackfruit bark extract against Salmonella typhi. The research parameter data observed were clear zones around disc paper that had been soaked in jackfruit bark extract with concentrations of 25\%, 50\%, 75\% and 100\%. Data were analyzed statistically using Kruskall-Wallis test at level $\alpha=0.005$ using SPSS 23.0 software, and Duncan's test to test differences between treatments. The test results showed that variations in the concentration of jackfruit bark extract affected the growth of Salmonella typhi bacteria, then from Duncan's test it was also known that 100\% treatment had the most significant or significantly different effect.
\end{abstract}

Keywords : Artocarpus heterophylus, Salmonella typhi, test for growth inhibition 


\section{PENDAHULUAN}

Salah satu tumbuhan yang sangat bermanfaat adalah nangka (Artocarpus heterophyllus). Hampir seluruh bagian tanaman nangka dapat dimanfaatkan sebagai obat tradisional, mulai dari daun, daging buah, biji nangka, daging buah, kayu, getah kulit batang dan kulit batang nangka, serta daun yang memiliki efek hipoglikemi sebagai obat anti diabetes. Menurut hasil penelitian bahwa daun Artocarpus integra mengandung saponin, flavonoida, dan tannin (Candrika, 2006), biji nangka berkhasiat sebagai obat batuk (Indonesia, 1987), bagian kayu mengandung senyawa kimia yaitu morin, sianomaklurin, flavon, dan tanin. Untuk bagian kulit batang nangka, berdasarkan hasil penelitian oleh Ersam (2001) terdapat senyawa fitokimia flavonoid yang baru seperti senyawa morusin, senyawa artonin E, sikloartobilosanton, dan senyawa artonol $\mathrm{B}$, dimana senyawa flavonoid tersebut dapat bersifat sebagai antimikroba.

Salah satu bakteri Gram negatif dari famili Enterobacteriaceae yaitu Salmonella thphii, merupakan bakteri yang patogen pada saluran pencernaan manusia, yang berasal dari makanan (foodborne disease) [Klotchko, 2011] dan penyakit yang disebabkan oleh bakteri ini kebanyakan bersifat menular (Poeloengan, 2014). Berbagai penelitian telah dilakukan untuk mengobati penyakit yang disebabkan oleh Salmonella typhi baik secara hebal tradisional maupun menggunakan obat sintetik. Penggunaan obat sintetik dalam jangka waktu yang lama, mengakibatkan efek negatif bagi tubuh manusia (Utami dan Desti, 2013), sehingga masyarakat lebih memilih pengobatan secara tradisional dengan memanfaatkan berbagai ekstrak tanaman yang memiliki senyawa flavonoid sebagai antimikroba.

Ekstrak kulit batang Nangka (Artocarpus heterophyllus) memiliki kandungan senyawa flavonoid, dimana senyawa ini berdasarkan hasil penelitian Patil dan Nikam (2013) bahwa kandungan flavonoid berperan sebagai antibakteri. Senyawa flavonoid pada ekstrak tanaman ini dapat bersifat sebagai antibakteri dengan cara merusak dinding sel bakteri sehingga dapat menembus membran sel dan menyebabkan inti sel mengalami lisis yang pada akhirnya menyebabkan kematian sel bakteri (Pasaribu et al., 2008). Berbagai penelitian yang menggunakan ekstrak tanaman dalam upaya mengatasi penyakit yang disebabkan oleh bakteri Salmonella typhi telah banyak dilakukan. Namun penelitian tentang ekstrak dari kulit batang nangka (Artocarpus heterophyllus) sebagai antibakteri terhadap Salmonella typhi belum banyak dilakukan, sehingga perlu 
dilakukan penelitian terkait pengujian ekstrak kulit batang nangka dalam menghambat pertumbuhan Salmonella typhi.

\section{METODE}

Pengujian ekstrak kulit batang nangka sebagai antibakteri ini dilakukan secara in vitro di Laboratorium Biologi IKIP PGRI Jember. Penelitian eksperimental ini dilakukan dengan menggunakan ekstrak kulit batang nangka (Artocarpus heterophylus) dengan konsentrasi sebesar $0,25,50,75$ dan 100 dan dilihat responnya terhadap terhadap diameter zona hambat pertumbuhan Salmonella typhi. Penelitian diulang sebanyak 5 kali.

Alat dan Bahan Penelitian. Peralatan yang digunakan yaitu Alat Maserasi, spatula, autoklaf, kain untuk menyaring ekstrak, blender untuk menghaluskan kulit batang nangka, timbangan analitik, Bunsen, kompor, labu Erlenmeyer, gelas Beaker, tabung reaksi, pipet volume, jarum ose, cawan Petri, gelas volume, alat pengaduk media dan LAF. Adapun bahan penelitian yaitu etanol 96\%, alkohol 75\%, alkohol 95\%, akuades steril, sarung tangan, masker, spiritus, media Nutrien Agar (NA), paper disk, kertas label, aluminium foil, Plastik Wraps, kertas label, kulit batang nangka (Artocarpus heterophylus) dan isolat bakteri Salmonella typhi yang dibeli dari Laboratorium Biologi IKIP PGRI Jember.

Pembuatan Media Nutrient Agar (NA). Menimbang komponen sebanyak 4,6 Gram media NA dalam $200 \mathrm{~mL}$ akuades dengan mengikuti perbandingan komposisi media Nutrient Agar 23 Gram/1000 mL. Media Nutrient Agar sebanyak 4,6 gram dimasukkan ke dalam beaker glass dan ditambah akuades sebanyak $200 \mathrm{~mL}$, dimasak di atas penangas air dan diaduk sampai homogen. Media NA dimasukkan ke dalam Erlenmeyer, kemudian dilakukan sterilisasi media menggunakan autoclave selama 15 menit $121^{\circ} \mathrm{C}$.

Pembuatan Starter dan Larutan NaCl. Menimbang $\mathrm{NaCl}$ sebanyak 4,5 gram, kemudian memasukkan $\mathrm{NaCl}$ ke dalam erlenmeyer, lalu menambahkan akuadest hingga $500 \mathrm{~mL}$. Selanjutnya mensterilisasi larutan $\mathrm{NaCl}$ dengan menggunakan autoclave. Setelah steril, memasukkan larutan NaCL $10 \mathrm{ml}$ ke dalam Erlenmeyer. Kemudian mengambil $1 \mathrm{~mL}$ strarter induk lalu ditambahkan ke dalam larutan garam fisiologis dan selanjutnya menghomogenkan. 
Tahap Uji Aktifitas Antibakteri Metode Difusi Agar. Pengujian ekstrak kulit batang nangka terhadap Salmonella typhi bertujuan untuk menguji aktivitasnya sebagai agen antibakteri, dimana pada penelitian ini menggunakan metode difusi dengan paper disk. Sebanyak $1 \mathrm{~mL}$ isolat bakteri uji yaitu Salmonella typhi yang telah dilakukan peremajaan sebelumnya serta telah dibiakkan pada media starter $\mathrm{NaCl}$, dimasukkan ke dalam cawan petri sebanyak yang perlakuan dan pengulangan. Selanjutnya, memsukkan $\pm 5 \mathrm{~mL}$ media NA yang masih cair dan menghomogenkannya dengan membentuk angka delapan secara halus sebelum media NA memadat. Setelah media berisi isolat mikroba uji, selanjutnya meletakkan paper disk (diameter 14,02 $\mathrm{mm}$ ) yang telah direndam selama 5 menit ke dalam berbagai konsentrasi perlakuan yaitu 0\%, 25\%, 50\%, 75\%, $100 \%$ dan meletakkan paper disk diatas permukaan media NA yang memadat sempurna. Seluruh cawan petri perlakuan diberi isolasi di bagian tepi dan dibungkus dengan plastic wraps untuk menghindari kontaminasi oleh mikroba lain maupun serangga, serta diinkubasi pada suhu ruang yaitu $37{ }^{\circ} \mathrm{C}$ selama $1 \times 24-2 \times 24$ jam, jika dibiarkan terlalu lama menyebabkan bakteri mengalami resistensi terhadap senyawa pada ekstrak kulit batang nangka sehingga tidak dapat diamati besar zona hambatnya. Pengamatan dilakukan dengan cara mengamati dan mengukur diameter zona bening di sekitar paper disk.

\section{HASIL DAN PEMBAHASAN}

Penelitian uji antibakteri ekstrak kulit batang nangka (Artocarpus heterophyllus) terhadap Salmonella typhi dilakukan menggunakan metode difusi cakram dengan paper disk berdiameter 14,02 mm yang sebelumnya telah direndam pada masing-masing konsentrasi ekstrak pada media NA yang telah di inokulasi bakteri Salmonella typhi sebagai bakteri yang akan diuji.

Untuk perlakuan uji daya hambat penelitian ini menggunakan konsentrasi sebesar $0 \%, 25 \%, 50 \%, 75 \%, 100 \%$ dengan 5 pengulangan untuk mengetahui daya hambat ekstrak kulit batang nangka terhadap Salmonella typhi serta diinkubasi pada suhu ruang yaitu $37{ }^{\circ} \mathrm{C}$ selama $1 \times 24-2 \times 24$ jam. Setelah inkubasi, jika terbentuk zona bening maka dilakukan pengukuran besar diameter zona bening di sekikat paper disk dengan menggunakan jangka sorong yang memiliki titik ketelitian 0,05 mm untuk menentukan kemampuan daya hambat ekstrak kulit batang nangka terhadap bakteri 
Salmonella typhi. Dikarenakan data diameter zona hambat yang diperoleh tidak menunjukkan hasil yang Normal pada pengujian Uji Normalitas Kolmogorov-Smirnov, maka analisis penelitian ini menggunakan uji Kurskall-Wallis 5\%.

Tabel 1: Hasil uji Kruskall Wallis zona hambat pertumbuhan Salmonella typhi

\begin{tabular}{lc} 
Test Statistics $^{\text {a,b }}$ \\
\hline \multicolumn{2}{c}{ Diameter Zona hambat } \\
\hline Chi-Square & 15.498 \\
Df & 4 \\
Asymp. Sig. & .004 \\
\hline
\end{tabular}

a. Kruskal Wallis Test

Tabel 2: Rerata diameter daya ekstrak kulit batang nangka terhadap bakteri S.typhi pada berbagai konsentrasi perlakuan

\begin{tabular}{cc}
\hline Perlakuan $(\mathrm{mg} / \mathrm{mL})$ & Rerata diameter $(\mathrm{mm})$ \\
\hline Konsentrasi 0\% & $0,00 \pm 0,000^{\mathrm{a}}$ \\
Konsentrasi $25 \%$ & $18,31 \pm 0,15^{\mathrm{b}}$ \\
Konsentrasi 50\% & $18,35 \pm 0,07^{\mathrm{b}}$ \\
Konsentrasi $75 \%$ & $18,68 \pm 0,44^{\mathrm{bc}}$ \\
Konsentrasi $100 \%$ & $19,02 \pm 0,43^{\mathrm{c}}$ \\
\hline
\end{tabular}

Hasil statistika menggunakan uji Kruskall Wallis menunjukkan bahwa ekstrak etanol kulit batang nangka (Artocarpus heterophylus) berpengaruh secara signifikan (sig 0.004) (tabel 1) untuk semua perlakuan konsentrasi terhadap diameter zona hambat pertumbuhan bakteri patogen Salmonella typhi. Dari hasil perlakuan uji daya hambat ekstrak kulit batang nangka, dapat diketahui jika pada konsentrasi 25\%, 50\%, 75\% dan 100\% menunjukkan adanya zona bening di sekitar kertas cakram, sedangkan pada konsentrasi $0 \%$ tidak ditemukan zona bening. Konsentrasi yang menunjukkan zona bening yang paling lebar pada konsentrasi 100\%, sedangkan pada konsentrasi $25 \%$ zona 
bening yang terbentuk lebih kecil dibandingkan dengan konsentrasi 50\%, 75\%, dan 100\%. Dari hasil pengamatan terhadap zona bening pada pertumbuhan bakteri Salmonella typhi menggunakan jangka sorong, menunjukkan hasil pengukuran diameter zona hambat pertumbuhan bakteri pada tiap konsentrasi ekstrak kulit batang nangka (tabel 2: Gambar 1).

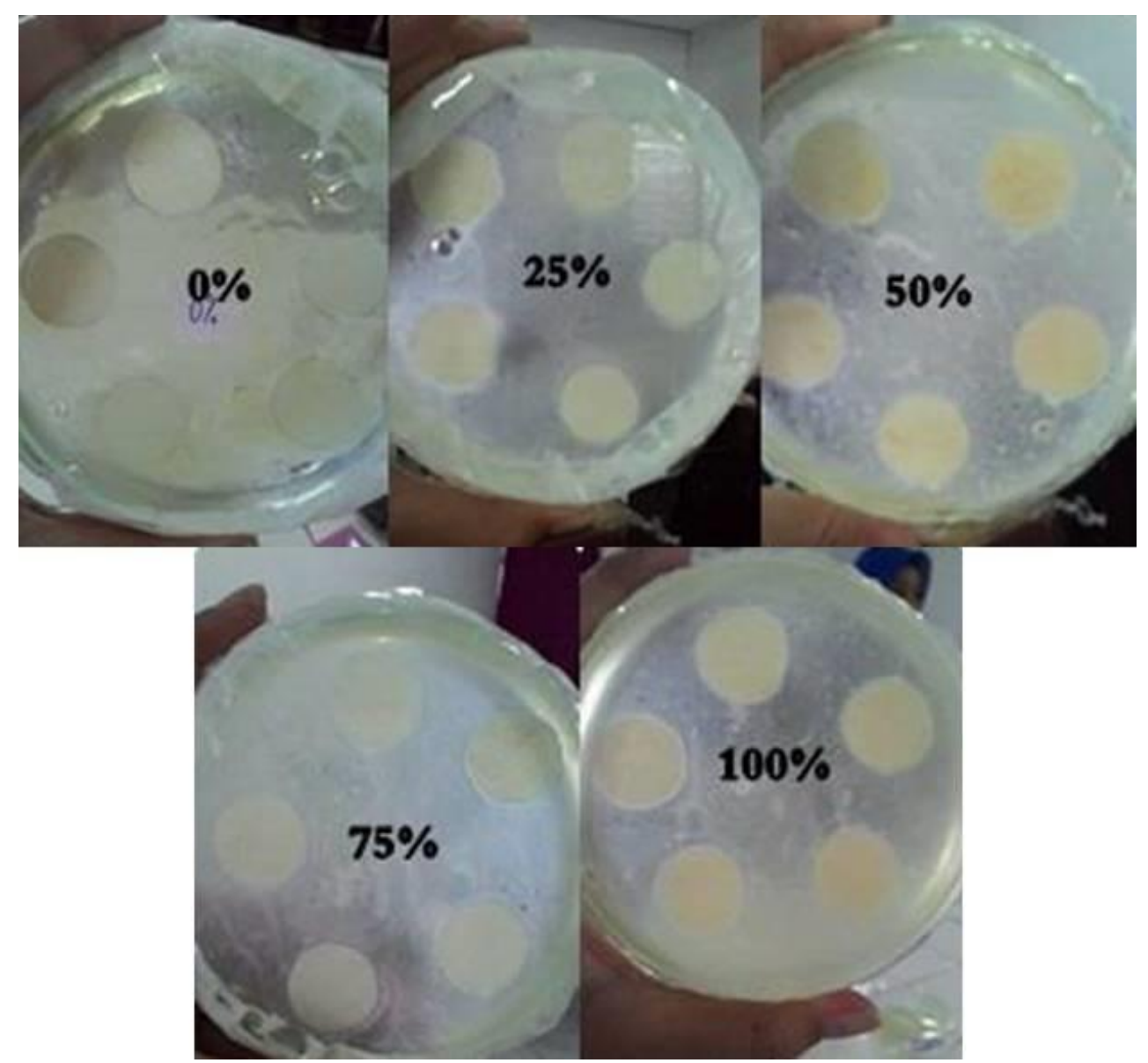

Gambar 1. Diameter zona hambat ekstrak batang nangka terhadap Salmonella thypii

Terbentuknya zona bening di sekitar kertas cakram menunjukkan adanya aktivitas antibakteri terhadap bakteri uji yaitu Salmonella typhi berpengaruh terhadap pertumbuhan bakteri Salmonella typhi, dikarenakan pada ekstrak kulit batang nangka memiliki kandungan senyawa yang dapat menghambat pertumbuhan mikroba yaitu flavonoid yang memiliki sifat sebagai agen lipofilik dan mampu merusak permeabilitas membran sel bakteri, bersifat adhesion pada mikroba (zat perekat yang terdapat pada fimbriae/pili), bersifat sebagai enzimatik, dan mengganggu protein transport protein 
pada membran sel bakteri (Naim, 2004). Selain itu, di dalam ekstrak kulit batang nangka juga mengandung senyawa fitokimia lain yaitu alkaloid yang juga berperan dalam menghambat bahkan membunuh sel bakteri Salmonella typhi dengan cara memanfaatkan sifat nya yang reaktif pada gugus basa untuk bereaksi dengan sel bakteri yang memiliki gugus asam amino (Pasaribu et al., 2008).

Hasil penelitian menunjukkan bahwa, seluruh perlakuan yang telah dilakukan menghasilkan diameter zona hambat yang berbeda-beda, serta menunjukkan konsentrasi yang lebih tinggi menghasilkan diameter zona hambat pertumbuhan Salmonella typhi yang lebih besar (tabel 2). Tingginya diameter zona hambat pada konsentrasi yang tinggi juga disebabkan kandungan senyawa fitokimia yang berperan sebagai senyawa antibakteri seperti flavonoid, alkaloid dan sebagainya. Penelitian yang sama dilakukan oleh Swantara dkk (2011) tentang uji aktivitas antibakteri fraksi kulit batang nangka terhadap Escherichia coli dan Staphylococcus aureus dengan beberapa perlakuan menunjukkan bahwa jika pemberian konsentrasi yang berbeda pada tiap perlakuan, akan memiliki pengaruh terhadap pertumbuhan bakteri E. coli yang juga semakin terhambat.

Berdasarkan hasil analisis dengan Kruskal Wallis taraf 5\%, terdapat perbedaan signifikan pada semua perlakuan ( $\operatorname{sig} 0,004<0,05)$, dimana pada konsentrasi $100 \%$ menunjukkan hasil yang lebih tinggi $\left(19.02 \pm 0,43^{c}\right)$ dibandingkan dengan konsentrasi lainnya $(0 \%, 25 \% 50 \%$, dan $75 \%)$. Pada perlakuan $75 \%$ dan $100 \%$ didapatkan diameter zona hambat pertumbuhan yang lebih besar, hal ini menunjukkan pada konsentrasi $75 \%$ keatas merupakan perlakuan paling optimal untuk menghambat pertumbuhan bakteri yang dikarenakan pada konsentrasi ini memiliki kandungan senyawa penghambat pertumbuhan bakteri yang lebih tinggi sehingga menghasilkan diameter zona hambat yang lebih besar (Pasaribu et al., 2008). Penelitian lainnya yang sejalan yaitu tentang aktivitas ekstrak kulit batang nangka dengan menggunakan pelarut air dan methanol dapat menghambat pertumbuhan bakteri E. coli dan pemberian ekstrak kulit batang nangka pada konsentrasi $95 \%$ adalah konsetrasi tertinggi yang memberikan respon hambatan yang paling optimal (Swantara dkk, 2011).

Pengujian aktivitas antibakteri ekstrak kulit batang nangka menggunakan metode difusi cakram dengan bakteri uji Salmonella typhi dengan konsentrasi ekstrak 0\% sebagai kontrol negatif dengan menggunakan aquades tanpa perlakuan ekstrak, dan $25 \%, 50 \%, 75 \%$ dan $100 \%$ dengan perlakuan ekstrak. Pengujian aktivitas antibakteri 
ekstrak kulit batang nangka menggunakan kontrol negatif sebagai pembanding untuk melihat pengaruh pelarut pada proses ekstraksi terhadap zona hambat yang dihasilkan (Permatasari, et al., 2013).

Tabel 3: Aktivitas antimikroba berdasarkan Zona Hambat

\begin{tabular}{cc}
\hline Aktivitas Fungi & Besar Zona Hambat $(\mathrm{mm})$ \\
\hline Lemah & $<10$ \\
Sedang & $10-15$ \\
Kuat & $16-20$ \\
Sangat Kuat & $>20$ \\
\hline
\end{tabular}

Sumber : Setyaningsih, 2017

Berdasarkan kriteria penentuan respon hambat pertumbuhan bakteri (Gambar 3) (Setyaningsih, 2017), rata-rata zoa hambat pada penelitian ini yaitu berkisar antara 16$20 \mathrm{~mm}$. Ketentuan respon hambatan pertumbuhan bakteri dibedakan menjadi 4 klasifikasi, jika diameter zona hambat $>20 \mathrm{~mm}$ menunjukkan jika respon hambatan kuat, jika besar diameter zona hambat antara 16-20 mm, maka respon hambatannya sedang, sedangkan jika diameter zona hambat antara 10-15 $\mathrm{mm}$, maka repon hambatannya lemah dan jika diameter zona hambatnya $<10 \mathrm{~mm}$, maka dapat dikatakan jika tidak ada respon terhadap hambatan pertumbuhan bakteri. Berdasarkan kriteria tersebut, ekstrak kulit buah nangka dalam menghambat pertumbuhan bakteri Salmonella typhi dengan konsentrasi terbesar yaitu 25\% hingga konsentrasi 100\% dengan diameter zona hambat sebesar 18,31 - 19,02 mm memiliki kemampuan antifungi yang kuat. Sedangkan pada perlakuan kontrol negatif tidak terbentuk zona bening, sehingga diperoleh hasil bahwa ekstrak kulit batang nangka yang berperan aktif dalam menghambat pertumbuhan Salmonella typhi. Ekstrak kulit batang nangka positif dapat menghambat pertumbuhan bakteri disebabkan adanya kandungan antibakteri pada kulit batang nangka, dimana terdapat flavonoid yang berperan sebagai antibakteri (Ersam, 2001).

Bakteri Salmonella typhi pada penelitian ini merupakan kelompok bakteri Gram negatif, dimana penyusun utama dinding selnya yaitu lipoprotein, fosfolipid, lipopolisakarida (LPS) dan protein dengan lapisan dinding tebal bilayer sehingga memiliki sifat patogenitas yang tinggi sehingga bakteri Salmonella typhi lebih sulit dihambat dibandingkan dengan bakteri Gram positif (Dzen, dkk, 2003). Sehingga 
dibutuhkan konsentrasi yang tinggi pada ekstrak kulit batang nangka untuk menghambat pertumbuhan bakteri Salmonella typhi karena konsentrasi yang tinggi akan menghasilkan senyawa antibakteri yang tinggi pula untuk menghambat pertumbuhan bakteri Salmonella typhi. Selain itu, kerja dari antibakteri dalam menghambat maupun membunuh sel bakteri dipengaruhi oleh banyak faktor, diantaranya besar kecilnya konsentrasi yang diberikan, lama waktu penyimpanan, suhu lingkungan inkubasi, jenis mikroba yang di uji, usia mikroba uji dan sebagainya (Pelczar dan Chan, 2006).

\section{KESIMPULAN DAN SARAN}

Simpulan dari penelitian ini yaitu ekstrak kulit batang nangka menunjukkan hasil yang optimal pada konsentrasi $100 \%$ dibandingkan konsentrasi lainnya dan memberikan perngaruh yang signifikan terhadap pertumbuhan bakteri Salmonella typhi. Saran penelitian ini yaitu, perlu dilakukan penelitian lanjut tentang mekanisme kerja senyawa ekstrak kulit batang nangka (Artocarpus heterophylus) dalam menghambat pertumbuhan bakteri Salmonella typhi, serta melakukan deteksi senyawa aktif yang terdapat pada tumbuhan Artocarpus heterophylus.

\section{DAFTAR PUSTAKA}

Chandrika, U. G., Wedage, W. S., Wickramasinghe, S. M. D., \& Fernando, W. S. (2006). Hypoglycaemic Action Of The Flavonoid Fraction Of. African Journal of Traditional, Complementary and Alternative Medicines, 3(2), 42-50.

Patil, D. G., \& Nikam, S. V. (2013). In vitro antimicrobial, antioxidant activity and phytochemical analysis of Cosmos caudatus Kunth (wild cosmos). Universal Journal of Pharmacy, 2(6), 64-70.

Dzen, Sjoekoer. M, dkk. 2003. Bakteriologik Medik. Malang: Bayumedia.

Ersam, T. (2001). Senyawa Kimia Mikromolekul Beberapa Tumbuhan Artocarpus Hutan Tropika Sumatra Barat. Disertasi, ITB, Bandung.

Indonesia, H. K. T. B. (1987). terjemahan Badan Litbang Kehutanan. Jilid II. Cetakan kesatu. Badan Penelitian dan Pengembangan Kehutanan. Departemen Kesehatan. Klotchko, 2011. A., Salmonellosis. Available from: http://emedicine.medscape.com/article/228174-overview. Diakses 09 april 2015 
Naim, R. (2004). Senyawa Antimikroba dari Tanaman [Online]. Tersedia: http://www2.kompas.com/kompas-cetak/0409/15/sorotan/1265264.htm (20 Juli 2008)

Pasaribu, S. P., Eva, M., \& Boby, S. N. (2008). Uji Fitokimia, Toksisitas dan Aktivitas Antibakteri Ekstrak Etanol Batang Jarak Cina (Jatropha multifida L.). Jurnal Kimia Mulawarman, 5(2).

Pelczar, M.J. dan Chan, E. C. S., 2006, Dasar-dasar Mikrobiologi Jilid 2, UI Press, Jakarta

Permatasari, G. A. A. A., Besung, I. N. K., \& Mahatmi, H. A. P. S. A. R. I. (2013). Daya hambat perasan daun sirsak terhadap pertumbuhan bakteri Escherichia coli. Indonesia Medicus Veterinus, 2(2), 162-169.

Poeloengan, M. A. S. N. I. A. R. I., Komala, I., \& Noor, S. M. (2014). Bahaya Salmonella terhadap kesehatan. JITV, 19(3).

Setyaningsih, I., Hardjito, L., Monintja, D. R., Sondita, M. F. A., Bintang, M., Lailati, N., \& Panggabean, L. (2017). Ekstrasi Senyawa Antibakteri Dari Diatom Chaetoceros gracilis dengan Berbagai Metode. Jurnal Biologi Indonesia, 5(1).

Swantara, I. M. D., Darmayasa, I. B. G., \& Dewi, N. (2011). Uji aktivitas antibakteri fraksi kulit batang nangka. Jurnal Kimiawi, 5(1), 1-8.

Utami, P., Puspaningtyas, D. E., \& Gz, S. (2013). The miracle of herbs. AgroMedia. 